DOI: https://doi.org/10.18371/fp.3(39).2020.215261

УДК 339.7

\title{
ОСОБЛИВОСТІ ІНТЕГРАЦІЇ УКРАЇНИ У МІЖНАРОДНИЙ РИНОК КАПІТАЛУ
}

\author{
ПЕТРОВА Ольга Олександрівна \\ кандидат економічних наук, \\ дочент кафедри економіки та фінансів \\ Херсонський державний аграрно-економічний університет \\ ORCID ID:http://orcid.org/0000-0001-8639-3615 \\ e-mail:petr17ant@gmail.com
}

\begin{abstract}
Анотація. $B$ статті розглянуто проблеми та перспективи інтеграчії України у світовий фінансовий ринок, зокрема, у ринок капіталу. Досліджено, шо для розвитку наиіональної економіки України необхідна інтеграиія $v$ міжнародний фінансовий простір, шо відповідає сучасним тендениіям глобалізаиії. Проаналізовано основні тендениї рvхv капіталів у сучасному фінансовому простоpi. Окреслено напрями державної політики розбудови ринку капіталу в Украӥні та усуненні проблем, щзо заважають його подальшому розвитку.

Ключові слова: світовий фінансовий ринок, світовий ринок капіталу, глобалізачія, інтеграція.
\end{abstract}

Постановка проблеми. Швидкий розвиток світової цивілізації характеризується активізацією глибоких змін у геополітичних та економічних інтересам суспільства. Характерним для сучасності є посилення взаємозалежності економічних систем різних країн, розповсюдження інтеграційного процесу на макро- та макрорівнях та інтенсивний пебрехід більшості країн iз закритих національних економік у відкриті. Водночас структурноекономічна трансформація розширює можливості консолідації фінансового капіталу у всій світовій економіці, враховуючи зростаючу роль фінансо-
Аннотация. B cmaтье рассмотрены проблемы и перспективы интеграчии Украины в мировой финансовый рынок, в частности, в рынок капитала. Исследовано, что для развития экономики Украинь необходима интеграиия в международное финансовое пространство, что соответствует современным тенденииям глобализаиии. Проанализированы основные тендениии движения капитала в финансовом пространстве. Выделены направления госvдарственной политики развития рынка капитала в Украине и устранения проблем, мешающих его развитию.

Ключевые слова: мировой финансовый рынок, мировой рынок капитала, глобализациия, интеграциия.

вої системи в умовах структурного та інноваційного розвитку української економіки. Важливість вибору правильних орієнтирів зовнішньоекономічної політики набуває особливої уваги в умовах посилення глобалізацій них тенденцій у світі та загострення конкурентного протистояння на світових ринках, в тому числі, й фінансових. Одна 3 найважливіших функцій фінансового ринку - це вільний перехід грошових коштів у позикові кошти, в результаті чого відбувається перерозподіл капіталу між різними економічними суб'єктами. Сучасні глобальні процеси у світовому економічному 
просторі тісно пов'язані з ринком капіталу, тобто, 3 механізмом накопичення та перерозподілу капіталу, який складається 3 ринку іноземних кредитів та позик, ринку фондового ринку тощо.

На сьогодні на ринку капіталу в Україні існує багато проблем. Так, недосконалість економічних методів управління ринком цінних паперів, відсутність дієвої державної політики та реальних фінансових інструментів $\mathrm{i}$ механізмів впливу на економічний розвиток країни вкрай негативно впливають на забезпечення економічної безпеки держави. Тому ці питання потребують негайного вирішення для запобігання поглинанню ринку капіталу України іншими, більш ікапіталізованими, країнами.

Аналіз останніх досліджень та публікацій. Провідні вітчизняні та зарубіжні науковці та економісти приділяють багато уваги проблемам і перспективам розвитку світового ринку капіталів. Так, О.Г. Білорус вважає, що «Інтеграція світової економіки в глобальну веде до втечі капіталів із відсталих країн, до втечі кваліфікованої робочої сили і інтелекту націй у передові країни» [1, с.7]. На думку А.О. Столяра «В умовах глобалізації міжнародних фінансів поступово зникає межа між внутрішнім (локальним) i міжнародним ринком капіталів» [2, c.12]. Батракова T.I. вказує, що «Світові ринки капіталу протягом останнього десятиріччя стрімко модернізувалися за всіма напрямами їх функціонування: правовим, інституційним та технологічним» [3, с.708]. Школьник O.I. відзначає, що «В умовах зростаючого впливу глобалізаційних процесів більш важливу роль відіграє міжнародний фінансовий ринок, який є пере- розподільним механізмом світових фінансових потоків... При цьому певний вплив на зміни, що відбуваються на міжнародному фінансовому ринку, мають нові ринки капіталу, до яких також належить і Україна» [4, с. 26].

Дослідивши праці провідних вчених, як В. Будкіна, Б. Губського, В. Новицького, В. Савчука, О. Шниркова та ін. стосовно розвитку процесів переміщення капіталу у міжнародному просторі в умовах глобалізаційних процесів, можна дійти висновку щодо прямого взаємозв'язку глобалізації i міжнародного фінансового капіталу. Як складова частина процесу глобалізації, фінансова глобалізація забезпечує вільний рух капіталів між країнами та регіонами, наднаціональне регулювання міжнародних фінансових потоків., посилення інтеграційної взаємодії національних економік.

Характерною рисою світових економічних відносин $є$ інтенсивний розвиток фінансової глобалізації із залученням національних економік до світового ринку капіталу, посилення їх взаємозалежності. Це стосується виникнення світового інформаційного простору, інтернаціоналізації та швидкого зростання ринків капіталу. В сфері світових фінансових відносин 3'являються нові тенденції та пріоритети. Тому розробка ефективної національної політики України в сфері фінансів з урахуванням необхідності інтеграції країни до світової економіки як рівноправного учасника глобального ринкового процесу $\epsilon$ стратегічно важливим напрямом. Глобалізація та іiі фінансова складова, міжнародна фінансова інтеграція як фактор, що впливає на неї, на сьогодні - недостатньо вивчені явища, тому дослідження в цій області дуже важливі та викли- 
кають великий теоретичний та практичний інтерес.

Мета статті. Метою статті є визначення місця України на світовому фінансовому ринку та обгрунтування стратегічних напрямів розвитку вітчизняного фінансового сектору в умовах глобалізаційних процесів для інтеграції країни до світової економіки.

Виклад основного матеріалу. Важливою передумовою забезпечення динамічного розвитку національної економіки України $є$ iї інтеграція у міжнародний фінансовий простір, що відповідає сучасним тенденціям глобалізації та необхідності поглиблення зовнішньоекономічних відносин країни 3 іншими державами світу. В першу чергу, це стосується проголошеного курсу на інтеграцію до Європейського Союзу, що має забезпечити поступову інтеграцію національної економіки до світової економічної системи, а відтак і підвищення глобальної конкурентоспроможності за умови ефективного та виваженого державного регулювання.

Фінансова сфера за рівнем глобалізації стоїть на першому місці серед інших сфер національних економік. Всі учасники ринку - уряди, банки, біржі, фінансові установи, інвестори та позичальники відчувають на собі вплив факторів та чинників фінансової глобалізації.

У найширшому сенсі фінансова глобалізація - це ідеологія, політика та практика об'єднання національних грошових систем через їх заміщення «світовими грошима» [5].

Примостка Л.О. та Чуб О.О. вважають, що «фінансова глобалізація - це процес об'єднання в єдину світову систему всієї сукупності міжнародних фінансових відносин та національних фінансових ринків 3 подальшим їх перетворенням у єдиний світовий фінансовий простір. Розвиток фінансової глобалізації забезпечує розширення кредитно-інвестиційної діяльності транснаціональних корпорацій і банків, формування міжнародних фінансових ринків, трансформацію фінансових систем держав, прискорення темпів інновацій, посилює взаємодію національних економік на базі сучасних інформаційних технологій і принципів регулювання, створює гнучкі ринки праці, товарів, капіталу» [6, с.179].

За визначенням I.Ю. Стукан «фінансова глобалізація - це вільний та ефективний рух капіталів між країнами та регіонами, функціонування глобального ринку, формування системи наднаціонального регулювання міжнародних фінансів, реалізація глобальних фінансових стратегій ТНК та транснаціональних банків» [7, с.19].

Як зауважує С.В. Онищенко «Фінансова глобалізація як полісистемний інтегрований об'єктивний процес $\epsilon$ результатом поглиблених фінансових зв'язків країн, лібералізації цін та інвестиційних потоків, створення глобальних транснаціональних фінансових груп і справляє подвійний вплив на розвиток світової фінансової системи» [8, c.54].

Фінансова глобалізація $є$ складним процесом, який може як позитивно, так і негативно впливати на розвиток суспільства в залежності від економічного рівня розвиту тієї чи іншої країни, а також іi політичного впливу в світі. Так, до позитивних наслідків фінансової глобалізації слід віднести появу глобальних комунікаційних мереж, посилення конкуренції на національних фінансових ринках, підви- 
щення мобільності та ліквідності капіталу, створення багатофункціонального фінансового ринку, спрощення процедури здійснення фінансових операцій тощо. Наслідки глобалізації для міжнародних фінансових ринків та для світової економіки в цілому проявляються у наступному: фінансова глобалізація призводить до переміщення фінансових потоків від сегментів ринку 3 великим ступенем ризику до сегментів, де рівень ризику невеликий, що позитивно впливає на стабільність світового фінансового простоpy.

Водночас, фінансова глобалізація може супроводжуватися такими негативними явищами, як зростання нестабільності національних фінансових ринків, обмеження доступу окремих учасників на світовий фінансовий ринок, висока ціна міжнародних позик, загроза виникнення та швидкого поширення фінансових криз із однієї економіки в іншу а також можливість іноземних банків контролювати весь цикл формування i використання фінансових потоків в державі [7, с.23].

Можна стверджувати, що саме фінансовий ресурс $є$ найбільш глобалізованим у світі. Про це свідчать досить великі обсяги обороту капіталу на валютному ринку та ринку цінних паперів.

Булатова О.В. та Марена Т.В. вважають, що «Фінансові активи як об'єкт відносин між суб'єктами світового фінансового ринку нерівномірно розподілені між країнами та регіонами світового господарства. Численні перетворення, що відбуваються у світовій фінансовій системі в умовах глобалізації, призводять до ще більш суттєвих зрушень у напрямках та масштабах перерозподілу капіталу як у со- ціально-економічному, так і у просторовому (регіональному) вимірах» [9, с.70].

Як визначає Г.М. Дроняєва, «відповідно до функціонального підходу світовий фінансовий ринок - це система ринкових відносин, у якій об'єктом операцій виступає грошовий капітал i яка забезпечує акумуляцію та перерозподіл світових фінансових потоків, створюючи умови для безперервності та рентабельності виробництва; відповідно до інституційного підходу світовий фінансовий ринок - це сукупність банків, спеціалізованих фінансовокредитних установ, фондових бірж, через які здійснюється рух світових фінансових потоків та які $є$ посередниками перерозподілу фінансових активів між кредиторами і позичальниками, продавцями та покупцями фінансових ресурсів» [10, с.7].

Формування глобальної фінансової архітектури супроводжується активізацією фінансового простору, зростанням світових фінансових потоків, розширенням масштабів фондових та кредитних ринків. На сучасному етапі розвитку світового фінансового ринку характерне значне нарощування потоків капіталу, насамперед, банківського, який навіть може випереджати торговельні потоки. Завдяки цим потокам відбувається прискорений перерозподіл сфер економічного впливу на національні і регіональні економічні середовища, оскільки потоки капіталів $\epsilon$ більш динамічними i чутливішими до змін економічного та інституційного середовища. Головними світовими експортерами та імпортерами капіталів, насамперед, у частині прямих іноземних інвестицій (ПII) $є$ найміцніші економіки. Так, наприклад, станом на 1 жовтня 2019 року країни Європейсь- 
кого союзу є найбільшими інвесторами в економіку України. За даними Держстату, на країни ЄС припадає $78 \%$ прямих іноземних інвестицій (ПII) в Україну. Зокрема, країни ЄС інвестували 27 205,8 млн дол США 3 34 727,6 млн дол США. Найбільшими інвесторами є Кіпр - 10303,2 млн дол США, Нідерланди - 7 556,5 млн дол США, Велика Британія 2 038,3 млн дол США, Німеччина 1 791,3 млн дол США. Інвестиції Росії в економіку України склали 817,9 млн дол США.

Потоки капіталів загалом характеризуються досить високою мінливістю, швидкою реакцією на національні і міжнародні фактори. Так, безпосередньо у докризовий період (з 2002 р. по 2007 р.) обсяги транскордонних потоків зросли у 6 разів, що узгоджувалось iз високою позитивною економічною динамікою, а також значними успіхами у зовнішньоекономічній лібералізації і дерегуляції. Однак, після глоба- льної кризи транскордонні потоки мають більш усталений характер із незначними коливаннями у діапазоні 4-6 трлн дол США. При цьому, світові інвестиційні потоки мали позитивні тенденції до зростання (при зменшенні банківського кредитування, насамперед, європейського, за кордон) [11, c.33].

Слід відзначити, що прямі іноземні інвестиції - найбільш бажана форма капіталовкладень для економік, що розвиваються, тому що вона дозволяє реалізовувати великі проекти; дозволяє надходити в країну новим технологіям, та новим практикам корпоративного управління. Прямі іноземні інвестиції представляють собою довгострокові вкладення матеріальних засобів компаніями-нерезидентами в економіку країни (наприклад, з метою організації і будівництва підприємств). Структура прямих іноземних інвестицій в Україні наведена в табл. 1.

Таблиця 1

Прямі іноземні інвестиції в Україні у 2019 році (млн. дол. США)

\begin{tabular}{|c|c|c|c|}
\hline Період & $\begin{array}{c}\text { Прямі іноземні інвес- } \\
\text { тиції в Україну }\end{array}$ & $\begin{array}{c}\text { Прямі іноземні ін- } \\
\text { вестиції з України }\end{array}$ & Сальдо \\
\hline I квартал & 508 & 1 & +507 \\
\hline II квартал & 578 & -1 & +579 \\
\hline III квартал & 637 & 0 & +637 \\
\hline IV квартал & 1347 & 648 & +699 \\
\hline Всього за рік & 3070 & 648 & +2422 \\
\hline
\end{tabular}

Джерело: [12]

Взагалі, якщо розглядати динаміку, можна зробити висновки, що прямі іноземні інвестиції в світі знижуються вже три роки поспіль. Так, у 2018 році вони скоротилися на 13\% до 1,3 трлн дол США, мінімального рівня з часів фінансової кризи. Багато в чому це пов'язано з геополітичними та торговими ризиками, які, можливо, продо- вжать негативно позначатися на інвестиціях в найближчі роки.

Глобальний клімат для міжнародної торгівлі та інвестицій вже не такий сприятливий, як раніше, коли світова економіка зростала завдяки експорту. Згідно з новими прогнозами Конференції ООН з торгівлі і розвитку, в період 2020-2021 років очікується скоро- 
чення потоків прямих іноземних інвестицій на 40\%. Це пов'язане з глобальним поширенням COVID-19 у світі , що впливає також і на укладення угод 3 міжнародних інвестиційних угод на майбутнє. Так, експерти спрогнозували: світ очікує потужна економічна криза у 2020 році. При цьому світова економіка цього року може втратити 3\% ВВП або 2,7 трлн дол США. Для України таке становище $є$ досить небезпечним, оскільки країна дуже вразлива 3 точки зору падіння цін на світових ринках. Так, потенційні втрати України за 2020-2021 роки можуть становити: падіння експорту (до 10 млрд дол США), зростання дефіциту торговельного балансу (до 13 млрд дол США), зниження кредитного рейтингу тощо.

3 метою розбудови ринку капіталу в Україні та усуненні проблем, що заважають подальшому розвитку ринків капіталу України, у 2020 році був прийнятий Закон України «Про внесення змін до деяких законодавчих актів України щодо спрощення залучення інвестицій та запровадження нових фінансових інструментів». При чому, цей закон викладає у новій редакції ЗУ «Про товарну біржу» та «Про цінні папери та фондовий ринок» зі зміною назви останнього на закон «Про ринки капіталу та організовані товарні ринки».

Закон визначає правові засади функціонування ринків капіталу та організованих товарних ринків, провадження професійної діяльності на зазначених ринках, врегульовує відносини, що виникають під час емісії та обігу цінних паперів, укладення й виконання деривативних контрактів та правочинів 3 ними. Закон спрямований на впровадження на ринках капіталу
України передової міжнародної практики, зокрема останніх законодавчих змін у Європейському Союзі та рекомендацій Міжнародної асоціації свопів та деривативів (ISDA). Закон сприятиме збільшенню інвестиції в економіку України, зокрема через підвищення довіри внутрішніх та іноземних інвесторів у результаті запровадження цивілізованих та уніфікованих правил на організованому ринку.

Крім того, Національний банк України, Національна комісія 3 цінних паперів та фондового ринку, Національна комісія, що здійснює державне регулювання у сфері ринків фінансових послуг (далі - регулятори), Міністерство фінансів України та Фонд гарантування вкладів фізичних осіб затвердили Стратегію розвитку фінансового сектору України до 2025 року. Метою Стратегії $є$ забезпечення подальшого реформування та розвитку фінансового сектору України відповідно до провідних міжнародних практик та імплементації заходів, передбачених Угодою про асоціацію між Україною та ЄC та іншими міжнародними зобов'язаннями України.

Стратегія передбачає розвиток фінансового сектору за п'ятьма основними напрямами:

- зміцнення фінансової стабільносTi;

- сприяння макроекономічному розвитку та зростанню економіки;

- розвиток фінансових ринків;

- розширення фінансової інклюзії;

- впровадження інновацій у фінансовому секторі.

Реалізація Стратегії 2025 створить умови для сталого зростання фінансового сектору України, підвищення його конкурентоспроможності в умовах 
інтеграції у світовий фінансовий ринок.

Висновки. Сучасне поглиблення фінансової глобалізації відбувається переважно за рахунок зростання обсягів іноземного банківського капіталу, валютних кредитів, іноземних прямих та портфельних інвестицій. У таких умовах держави втрачають можливості ефективно використовувати традиційні важелі макроекономічного регулювання, проте їхня роль в умовах фінансової глобалізації неоліберального типу зростає і полягає, з одного боку, у необхідності проведення послідовної й адекватної фіскальної політики, орієнтованої на створення умов для зростання конкурентоспроможності економіки у контексті базових національних інтересів, а 3 іншого - у активізації своєї діяльності у процесах міжнародної фінансової координації, стандартизації вимог, правил і норм, уніфікації та міждержавного узгодження заходів економічної політики, зокрема для запобігання і нейтралізації наслідків перманентних фінансових криз.

Основними елементами стратегії виходу України на світовий фінансовий ринок повинні стати реалізація загальнодержавних проектів розвитку, визначення інвестиційного клімату та інвестиційного потенціалу держави, збільшення ступеня впливу фінансових інструментів на розвиток економіки. Така стратегія орієнтована на визначення стратегічних перспективних цілей в умовах глобалізацій них процесів, які корегуються зовнішньоекономічним середовищем та визначають економічну незалежність України. Для цього необхідна розбудова сучасної інфраструктури фінансового ринку на державному та регіональному рівнях на засадах розвитку фінансових інститутів. По-друге, в Україні необхідно створення нових інструментів ринку капіталу, що дасть можливість виходу на зовнішні ринки $з$ фінансовими послугами, що мають високий комерційний потенціал. Крім того, необхідно створити певні інституціональні передумови для загальнодержавного поєднання різновидів капіталу для досягнення конкурентоспроможності національної економіки на світовому фінансовому ринку. Тобто, в довгостроковій перспективі важливим напрямом соціально-економічної політики України $є$ інтеграція у світове фінансове середовище.

\section{Список використаної літератури}

1. Білорус О.Г. Соціальна глобалістика: економіко-правові імперативи. Соціологія права, 2011. № 1 URL: http://dspace.nbuv.gov.ua/handle/123456789/39574 (дата звернення 28.08.2020).

2. Столяр А.О. Міжнародний ринок капіталів як невід'ємний елемент світових фінансів. Економічний часопис XXI. № 7-8, 2011, с.11-14.

3. Батракова T.I. Інтеграція України у світовий ринок капіталу: проблеми та перспективи . Економіка і суспільство. №7, 2016 с.707-710. 
4. Школьник I.О. Фінансовий ринок України в контексті розвитку світової фінансової системи: монографія. Суми:УАБС НБУ, 2007. 98с.

5. Макушкин А. Финансовая глобализация. Свободная мысль-ХХI, 1999. № 10 (1488). С. 30-43.

6. Примостка Л.О., Чуб О.О. Фінансова глобалізація: сутність, форми прояву, наслідки. Фінанси, облік і аудит, 2011. № 18. С. 172-183.

7. Стукан І.Ю. Фінансова глобалізація: сутність, етапи та наслідки. Європейські перспективи, 2015. № 1. С. 18-24

8. Онищенко С.В. Фінансова глобалізація як чинник впливу на бюджетну безпеку держави. Науковий вісник Уэсгородського національного університету. Серія: Міжнародні економічні відносини та світове господарство. Вип. 12, част.2, 2017. С. 50-55.

9. Булатова О.В., Марена Т.В. Зрушення регіональної структури світового фінансового ринку. Економічний вісник НТУУ «КПI», 2019. №16. С. 67-78.

10. Дроняєва Г.М. Розвиток світового фінансового ринку в аспекті формування глобального економічного простору : автореф. дис.. на здобуття наук. ступеня канд. економ.наук : 08.00.02. Донецьк, 2010. 22 с.

11. Торговельні війни сучасності та їх вплив на економічне зростання і розвиток у світі та Україні / за ред. В.Юрчишин. Київ: Заповіт, 2019. 190 с.

12. Прямі іноземні інвестиції в Україні в 2019 році. URL: https://index.minfin.com.ua/ua/minfin/sitemap/ (дата звернення 28.08.2020). 